\title{
Vertebrate responses to surface wildfires in a central Amazonian forest
}

Carlos A. Peres, Jos Barlow and Torbjørn Haugaasen

\begin{abstract}
Surface fires have recently become a widespread pantropical phenomenon that could trigger revolutionary changes in the structure and functioning of tropical forests and result in a catastrophic impoverishment of the vertebrate fauna. Here we describe the short- and medium-term responses of bird and mammal assemblages to an unprecedented wildfire that scorched the understorey of $1,100 \mathrm{~km}^{2}$ of forest in the ArapiunsMaró river basin of central Brazilian Amazonia. Fireinduced mortality in the aftermath of this burn was high for a wide range of plant and animal populations monitored. This included an average of $36 \%$ of all large trees in eight quarter-hectare plots sampled in burnt
\end{abstract}

forest, which dramatically altered the post-burn understorey light environment. The Arapiuns wildfire also resulted in significant socioeconomic costs to local forest dwellers, namely crop losses and the decimation of many forest resources, including key game vertebrate species pursued by subsistence hunters, vines and woody lianas, and many fruit species. The conservation prospects of the vertebrate fauna in fire-prone Amazonian forests are discussed with respect to the increasingly more frequent and severe El Niño-mediated dry seasons.

Keywords Amazonia, disturbance, fire, flammability, forest, hunting, selective logging, vertebrates.

\section{Introduction}

Moist evergreen tropical forests have long been assumed to be virtually immune to fires, yet the flammability threshold of a large but unknown proportion of this biome has been breached by severe droughts mediated by recent El Niño/Southern Oscillation (ENSO) events (Cochrane et al., 1999; Siegert et al., 2001). Such extreme hydrological deficits, when combined with an intentional or accidental source of ignition, can result in widespread wildfires with potentially catastrophic consequences for forest wildlife.

Surface fires initially appear to be relatively innocuous because they affect primarily the forest understorey rather than the canopy. However, they can set in motion an irreversible process of ecosystem transition with far reaching consequences for biodiversity. Such sub-canopy fires can trigger a positive feedback process in which the initial tree and liana mortality opens up the canopy, accelerates the rate of understorey desiccation, and augments the overall fuel load, all of which aggravate the risk of subsequent fires of increasingly greater severity (Uhl \& Buschbacher, 1985; Peres, 1999a; Cochrane et al., 1999). This could trigger a process of biomass collapse

Carlos A. Peres (Corresponding author) Jos Barlow and Torbjørn Haugaasen, Centre for Ecology, Evolution \& Conservation, School of Environmental Sciences, University of East Anglia, Norwich, NR4 7TJ, UK. Email: c.peres@uea.ac.uk

Received 18 January 2002. Revision requested 17 June 2002 Accepted 23 September 2002 over the course of several ENSO events, with millions of hectares of closed-canopy evergreen forests being converted into scrub savannahs of substantially lower value in terms of both biodiversity and key ecosystem services. Surface fires have emerged as a widespread pantropical phenomenon threatening to become the single most important agent of disturbance in highly seasonal tropical forests (Goldammer, 1999). However, biomass burning routinely serves multiple functions for millions of tropical forest dwellers worldwide, including forest clearance, soil fertilisation, correction of acidic soil $\mathrm{pH}$, and control of competitive weed species. Potentially flammable forests are therefore likely to burn repeatedly because anthropogenic or natural sources of ignition are often available and appropriate fire management practices are often lacking.

Here we describe the short- and medium-term impacts of an unprecedented surface fire, which took place in December 1997, on the forest wildlife of the lower Tapajós-Madeira interfluvial basin of central Brazilian Amazonia. We describe some general vertebrate responses in the immediate aftermath of the fires, summarize faunal differences in sensitivity to fire disturbance, and describe fire-induced changes in forest structure and their interactions with other threats to wildlife such as subsistence hunting. We also consider the socioeconomic costs of wildfires to local stakeholders in terms of crop losses and reduced benefits accruable from burnt forest, and discuss how a shift to a recurrent fire regime could be detrimental to the original vertebrate fauna, while dramatically simplifying the guild structure of the residual assemblage. 


\section{Study area}

This study took place in the Arapiuns and Maró river basins of central Brazilian Amazonia (Fig. 1). These first and second order tributaries of the lower Tapajós river are fed by a clear-water catchment that has no contact with the nutrient-rich alluvial sediments from the upper Amazon. The study area lies $120 \mathrm{~km}$ west of Santarém, a large market town $(176,834$ residents in 2000) of western Pará.

A large portion of the study area lies within the 647,611 ha of the recently created Tapajós-Arapiuns Extractive Reserve (RETA), which was decreed in November 1998, a year after the wildfire. The reserve is occupied by c. 16,000 inhabitants of mixed European and Indian descent (caboclos) engaged in small-scale farming of cassava and other food crops, extraction of non-timber resources such as Brazil nuts and game vertebrates, and small-scale manufacture of dugout canoes and larger wooden boats made possible by selective logging of Mezilaurus itauba (Lauraceae) trees. The Amazon National Park, which encompasses 994,000 ha of forest $110-275 \mathrm{~km}$ south-east of the study area, is the only strictly protected area in the lower Madeira-Tapajós interfluvium. However, this park has become increasingly threatened by illegal logging activities and other interests (Greenpeace, 2001), even though it was the first reserve created in Amazonia.

The potential flammability of the forest of the ArapiunsMaró basin is aggravated by its predominantly sandy and permeable soils that lie within a zone of maximum fire risk in Amazonian forests (Nepstad et al., 1999). Unlike other seasonal Amazonian forests sustained primarily by clay soils (Uhl \& Buschbacher, 1985; Holdsworth \& Uhl, 1997), human-induced canopy disturbance resulting from selective logging is not a necessary precondition
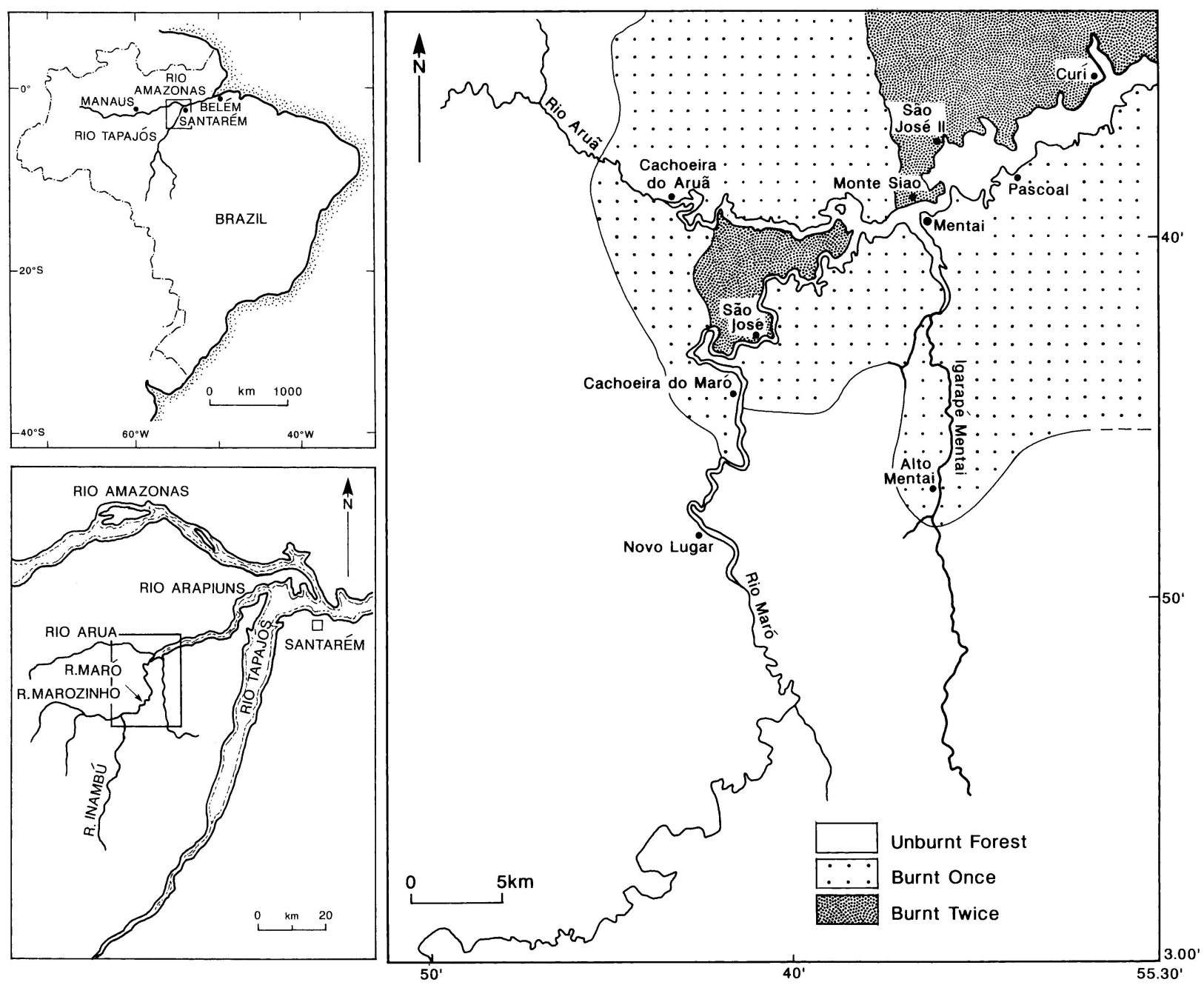

Fig. 1 Location of the study area along the Maró river illustrating the extent of once-burnt, twice-burnt, and unburnt forests. All forest areas between the Arapiuns and Amazon rivers, and between the Arapiuns and lower Tapajós rivers, were also reported to have burnt. 
for reaching the point of leaf litter flammability in this region. The surface fire triggered by the 1997-98 El Niño dry season was able to propagate even in unlogged primary forest (Peres, 1999a, 2000), and previous forest fires in local living memory (1968 and 1991) were trivial in extent and severity compared to that reported here.

The catchments of the lower Madeira-Tapajós interfluvium harbour a rich vertebrate fauna including a number of endemic vertebrate species that are poorly represented in existing nature reserves. The list of bird and mammal species that are partly or entirely endemic to this region (Table 1) underestimates the true level of endemicity because, unlike the fauna on the east bank of the lower Tapajós, the small mammal (bats, rodents and marsupials) and herpetological fauna are yet to be surveyed.

There are 10 primate taxa known to occur on the lower Tapajós-Madeira interfluvium (Table 2), which makes the primate assemblage more species-rich than other parts of central Amazonia east of the Rio Madeira. Of these, white-nosed bearded sakis Chiropotes albinasus and white-whiskered spider monkeys Ateles marginatus are the most sensitive to forest disturbance, and $A$. marginatus is already locally extinct in many parts of the Arapiuns region. Moreover, the small geographic ranges of tasseleared marmoset Callithrix humeralifera, Hoffmann's titi monkeys Callicebus hoffmannsi, and red-handed howler Alouatta belzebul epiphenotype nigerrima coincide with the most fire-prone forests of central Amazonia.

The 19 species of woodcreeper (Dendrocolaptidae) known from our study sites represents the highest basinwide diversity for this family (Oren \& Parker, 1997). The five species listed as endemic to the Tapajós-Madeira interfluvium by Oren \& Parker (1997) have also been recorded within the Maró-Arapiuns region (Table 1). In addition, the area harbours the restricted-range

Table 1 Conservation status of endemic and rare bird and mammal species occurring in the lower Tapajós-Madeira interfluvium.

\begin{tabular}{|c|c|c|c|c|}
\hline \multirow[b]{2}{*}{ Species } & \multirow[b]{2}{*}{ C.I. ${ }^{1}$} & \multirow[b]{2}{*}{ Status $^{2}$} & \multicolumn{2}{|c|}{ Sensitivity to disturbance ${ }^{3}$} \\
\hline & & & Fire & Hunting \\
\hline \multicolumn{5}{|l|}{ Mammals } \\
\hline Tassel-eared marmoset Callithrix humeralifera & $\mathrm{E}$ & $\mathrm{LR} / \mathrm{nt}$ & - & - \\
\hline Hoffmann's titi monkey Callicebus hoffmannsi & $\mathrm{E}$ & $\mathrm{LR} / \mathrm{nt}$ & - & - \\
\hline Red-handed howler Alouatta belzebul nigerrima ${ }^{4}$ & $\mathrm{E}$ & VU & - & ++ \\
\hline Bearded saki monkey Chiropotes albinasus & RE & VU & ++ & ++ \\
\hline White-whiskered spider monkey Ateles marginatus ${ }^{5}$ & RE & $\mathrm{EN}$ & ++ & +++ \\
\hline Giant river otter Pteronura brasiliensis & LR & VU & $?$ & +++ \\
\hline Bush dog Speothos venaticus & LR & VU & ? & + \\
\hline Small-eared dog Atelocynus microtis & LR & DD & $?$ & + \\
\hline Giant armadillo Priodontes maximus & LR & $\mathrm{EN}$ & ++ & +++ \\
\hline Giant anteater Myrmecophaga tetradactyla & LR & VU & ++ & ++ \\
\hline \multicolumn{5}{|l|}{ Birds } \\
\hline Harpy eagle Harpia harpyja & LR & $\mathrm{LR} / \mathrm{nt}$ & $?$ & +++ \\
\hline Crested eagle Morphnus guianensis & LR & $\mathrm{LR} / \mathrm{nt}$ & $?$ & +++ \\
\hline Ornate hawk eagle Spizaetus ornatus & LR & $\mathrm{LR} / \mathrm{nt}$ & $?$ & ++ \\
\hline White-browed hawk Leucopternis kuhli & LR & $\mathrm{LR} / \mathrm{nt}$ & + & + \\
\hline White-crested guan Penelope pileata & $\mathrm{E}$ & $\mathrm{LR} / \mathrm{nt}$ & ++ & ++ \\
\hline Hyacinth macaw Anodorhynchus hyacinthinus & $\mathrm{RM}$ & VU & $?$ & ++ \\
\hline Red-necked aracari Pteroglossus bitorquatus & $\mathrm{RE}$ & $\mathrm{LR} / \mathrm{nt}$ & - & + \\
\hline Hoffman's woodcreeper Dendrocolaptes hoffmannsi & RE & $\mathrm{LR} / \mathrm{nt}$ & ++ & - \\
\hline Pale-faced antbird Skutchia borbae & E & VU & +++ & - \\
\hline Harlequin antbird Rhegmatorhina berlepschi & $\mathrm{E}$ & $\mathrm{LR} / \mathrm{nt}$ & +++ & - \\
\hline Snow-crowned manakin Pipra nattereri & $\mathrm{E}$ & $\mathrm{LR} / \mathrm{nt}$ & - & - \\
\hline
\end{tabular}

${ }^{1}$ Conservation importance: E, endemic species largely or entirely restricted to the lower Tapajós-Madeira interfluvium; RE, regional endemic restricted to the southern bank of the Amazon east of the Madeira river; LR, locally rare throughout its geographic range; RM, rare migrant in Amazonian forests.

${ }^{2}$ IUCN conservation status: DD, Data Deficient; LR/nt, Lower Risk/near threatened; VU, Vulnerable; EN, Endangered (based on: Rylands et al., 1995; Stotz et al., 1996; Baillie \& Groombridge, 1995; IUCN, 2002).

${ }^{3}$ Sensitivity to disturbance is graded as following: - largely insensitive occurring in burnt and/or 'over-hunted' forest sites; + fairly, ++ , very and +++ extremely sensitive based on numerical abundance and prevalence of local extinctions in either burnt or 'over-hunted' forest;

${ }^{4}$ A. b. nigerrima has been considered to be a 'good' species, and occurs in localized populations north of the Amazonas river and west of the Madeira river (A. Rylands, pers. comm.).

${ }^{5}$ Reported to occur in the upper Maró river, but absent in the areas sampled. 
Table 2 Modal shifts in population abundance of medium and large bodied vertebrate species in unburnt (UH) and burnt (BH) forest sites in the lower Maró river (3 years after the wildfire) that had been moderately to heavily hunted, compared to those at an un-hunted and unburnt (UU) site in the upper Maró river (Oito de Maio). Population density estimates at UU are based on transect surveys (see text for details). Abundance shifts in $\mathrm{UH}$ are from $\mathrm{UU}$, and those in $\mathrm{BH}$ are from $\mathrm{UH}$. These were documented based on extensive personal observations over a 3-year period, confirmed by local interviews.

\begin{tabular}{|c|c|c|c|c|c|c|c|c|}
\hline \multirow[b]{2}{*}{ Species } & \multicolumn{6}{|c|}{ UU (Oito de Maio) } & \multirow[b]{2}{*}{$\mathrm{UH}^{5}$} & \multirow[b]{2}{*}{$\mathrm{BH}^{5}$} \\
\hline & Group size ${ }^{1}$ & $\mathrm{~N}^{2}$ & $\mathrm{DI}^{3}$ & $\begin{array}{l}\text { Groups } \\
\text { per } \mathrm{km}^{2}\end{array}$ & $\begin{array}{l}\text { Individuals } \\
\text { per } \mathrm{km}^{2}\end{array}$ & Model $^{4}$ & & \\
\hline \multicolumn{9}{|l|}{ Primates } \\
\hline Tassel-eared marmoset Callithrix humeralifera & 4.6 & 32 & 1.21 & 7.9 & 36.5 & $\mathrm{H}-\mathrm{N}$ & $\approx$ & + \\
\hline Hoffmann's titi monkey Callicebus hoffmannsi & 3.0 & 15 & 0.57 & 3.4 & 10.2 & $\mathrm{H}-\mathrm{N}$ & $\approx$ & ++ \\
\hline Red-necked night monkey Aotus nigriceps & - & - & - & $\mathrm{p}^{6}$ & $\mathrm{p}^{6}$ & - & $\approx$ & - \\
\hline Golden-backed squirrel monkey Saimiri ustus & - & - & - & $a^{6}$ & $a^{6}$ & - & $\approx$ & + \\
\hline Brown capuchin Cebus apella & 7.2 & 48 & 1.82 & 7.6 & 54.8 & Haz & - & --- \\
\hline White-fronted capuchin Cebus albifrons & 12.0 & 9 & 0.34 & 1.2 & 14.2 & NEx & - & + \\
\hline Bald-faced saki Pithecia irrorata & 3.6 & 13 & 0.49 & 2.5 & 8.9 & NEx & - & --- \\
\hline White-nosed bearded saki Chiropotes albinasus & 8.8 & 14 & 0.53 & 2.8 & 24.8 & NEx & - & + \\
\hline Red-handed howler Alouatta belzebul & 3.9 & 30 & 1.14 & 4.9 & 19.5 & NEx & - & $\approx$ \\
\hline White-whiskered spider monkey Ateles marginatus & - & - & - & $a^{6}$ & $a^{6}$ & - & + & + \\
\hline \multicolumn{9}{|l|}{ Ungulates } \\
\hline Gray brocket deer Mazama gouazoubira & 1.3 & 8 & 0.30 & 1.4 & 1.8 & NEx & - & $\approx$ \\
\hline Red brocket deer Mazama americana & 1.2 & 9 & 0.34 & 1.5 & 1.8 & NEx & - & $\approx$ \\
\hline White-lipped peccary Tayassu pecari & 70.0 & 3 & 0.11 & 0.7 & 4.8 & King & + & + \\
\hline Collared peccary Tayassu tajacu & 4.3 & 3 & 0.11 & 0.3 & 1.2 & King & -- & $\approx$ \\
\hline Lowland tapir Tapirus terrestris & 1.0 & 2 & 0.08 & 0.6 & 0.6 & King & --- & + \\
\hline \multicolumn{9}{|l|}{ Rodents } \\
\hline Pygmy squirrel Sciurillus pusillus & 1.5 & 4 & 0.15 & 1.5 & 2.3 & King & $\approx$ & + \\
\hline Southern Amazon red squirrel Sciurus spadiceus & 1.0 & 2 & 0.08 & 0.8 & 0.8 & King & $\approx$ & -- \\
\hline Guianan squirrel Sciurus aestuans & 1.0 & 7 & 0.27 & 4.4 & 4.4 & King & $\approx$ & $\approx$ \\
\hline Agouti Dasyprocta agouti & 1.0 & 307 & 11.64 & 52.6 & 53.8 & Haz & - & $\approx$ \\
\hline Paca Agouti paca & - & - & - & $\mathrm{p}^{6}$ & $\mathrm{p}^{6}$ & - & -- & $\approx$ \\
\hline \multicolumn{9}{|l|}{ Edentates } \\
\hline Nine-banded armadillo Dasypus novemcinctus & - & - & - & $\mathrm{p}^{6}$ & $\mathrm{p}^{6}$ & - & - & + \\
\hline Greater armadillo Dasypus kappleri & - & - & - & $\mathrm{p}^{6}$ & $\mathrm{p}^{6}$ & - & - & -- \\
\hline Giant armadillo Priodontes maximus & - & - & - & $\mathrm{p}^{6}$ & $\mathrm{p}^{6}$ & - & -- & + \\
\hline Collared anteater Tamandua tetradactyla & 1.0 & 3 & 0.11 & 0.5 & 0.5 & King & $\approx$ & - \\
\hline Giant anteater Myrmecophaga tridactyla & 1.0 & 1 & 0.04 & 0.8 & 0.8 & King & $\approx$ & + \\
\hline \multicolumn{9}{|l|}{ Other mammals } \\
\hline Coati Nasua nasua & 11.0 & 2 & 0.08 & 0.8 & 3.9 & King & - & $\approx$ \\
\hline \multicolumn{9}{|l|}{ Game birds } \\
\hline Dark-winged trumpeter Psophia viridis & 6.4 & 37 & 1.40 & 8.1 & 51.9 & $\mathrm{H}-\mathrm{N}$ & - & + \\
\hline Marbled woodquail Odontophorus gujanensis & 3.4 & 18 & 0.68 & 8.4 & 28.7 & $\mathrm{H}-\mathrm{N}$ & $\approx$ & + \\
\hline Guans Penelope spp. ${ }^{7}$ & 1.8 & 21 & 0.80 & 2.9 & 5.2 & Haz & - & + \\
\hline Razor-bill curassow Mitu tuberosa & 1.2 & 14 & 0.53 & 1.5 & 1.8 & King & --- & + \\
\hline Common piping guan Aburria pipile & 1.6 & 12 & 0.46 & 2.1 & 3.2 & NEx & -- & + \\
\hline Small tinamous Crypturellus spp. & 1.3 & 29 & 1.10 & 6.7 & 8.4 & Nex & $\approx$ & + \\
\hline Gray and Great tinamou Tinamus spp. & 1.1 & 47 & 1.78 & 9.7 & 11.0 & $\mathrm{H}-\mathrm{N}$ & -- & --- \\
\hline \multicolumn{9}{|l|}{ Reptiles (Testudines) } \\
\hline Red-footed tortoise Geochelone carbonaria & 1.1 & 70 & 2.65 & 10.5 & 11.5 & $\mathrm{H}-\mathrm{N}$ & -- & + \\
\hline Yellow-footed tortoise Geochelone denticulata & 1.1 & 32 & 1.21 & 4.8 & 5.1 & $\mathrm{H}-\mathrm{N}$ & -- & + \\
\hline
\end{tabular}

${ }^{1}$ Mean group size obtained from reliable counts.

${ }^{2}$ Number of independent detection events.

${ }^{3}$ Detection index (number of sightings per $10 \mathrm{~km}$ walked)

${ }^{4}$ Best-fit models used to derive density estimate with DISTANCE (Buckland et al., 2001): H-N, half-normal; Haz, hazard rate; Nex, negative exponential; King, King's method (used in cases of insufficient sample sizes).

${ }^{5}$ Magnitude and direction of population abundance shifts from UU to UH and from UH to BH: + , marked increase; $\approx$, approximately the same; - , marked decline; + , locally extinct.

${ }^{6} \mathrm{p}$, present along one of the three transects but density estimate unavailable; a, known to occur in the upper Maró river, but absent from the survey area.

${ }^{7}$ Includes two congeners which could not always be unambiguously distinguished in the field: the larger white-crested guan Penelope pileata and the smaller rusty-margined guan Penelope superciliaris. 
brown-chested barbet Capito brunneipectus and barbreasted piculet Picumnus borbae, and is used seasonally by northern migrant hyacinth macaws Anodorhynchus hyacinthinus. The Tapajós-Madeira interfluvial region also contains a number of bird species that are primarily restricted to the north of the Amazon river such as the green-tailed jacamar Galbula galbula and the ferruginousbacked antbird Myrmeciza ferruginea, and the Rio Maró basin is the only confirmed area where the black-faced hawk Leucopternis melanops occurs south of the Amazon (Barlow et al., 2002b).

\section{Methods}

We carried out a total of 18 months of fieldwork from January 1998 to July 2001. Forest structure and composition were sampled within 20 quarter-hectare plots $(10 \times 250 \mathrm{~m})$ in both burnt and unburnt forest. Eight plots were in burnt forest, eight in unburnt, and four ran perpendicular to and intersected the fire-line (a clearly distinguishable line that marked the extent of the fires). We carried out understorey mist-netting (beginning 10 months after the fires) for the diurnal avifauna within the Maró basin using 20 lines of 24 mist nets (12 m long, mesh size $36 \mathrm{~mm}$ ), placed at least $500 \mathrm{~m}$ apart, in a straight line intersecting the length of the quarter-hectare forest plots (Barlow et al., 2002a). Nets were opened for 30 h over 2.5 days without rain (05.30-17.30 for the first 2 days; $05.30-11.30$ on the third day) giving a total of 14,400 net-hours. All birds were identified to species, measured, weighed, and ringed with colour bands unique to each line. Net-lines were located in both burnt and unburnt forest on both banks of the Maró river, and two net-lines were placed $40 \mathrm{~km}$ upstream to serve as control samples distant from the fire. Four of the 20 net-lines were placed perpendicular to the fire-line separating burnt and unburnt forest to examine whether differences in capture rates in burnt forest could be detected at short distances from unburnt forest. All other net-lines were placed at least $500 \mathrm{~m}$ from the fire-line to minimise any potential spill-over effects.

We surveyed for vertebrates in an undisturbed forest site in the upper Maró river (Oito de Maio, 2 ${ }^{\circ} 59^{\prime} 58^{\prime \prime} \mathrm{S}$, $56^{\circ} 05^{\prime} 36^{\prime \prime} \mathrm{W}$ ) that had not been burnt and where there had been little or no hunting for the last 50 years. This survey took place in December 2000 and involved a two-way census effort of $263.8 \mathrm{~km}$ walked along three transects (two of $5 \mathrm{~km}$ and one of $4 \mathrm{~km}=14 \mathrm{~km}$ of transects) that had been cut through the forest and marked out every $50 \mathrm{~m}$. Census walks were conducted from 06.15 to 10.15 and 13.45 to 17.45 on 18 days without rain over a 1-month period, and resulted in 974 animal (or animal group) sightings. Upon a detection event, the time, species identity, group size, group spread, perpendicular distance to the animal, sighting location along the transect, and detection cue was recorded. Although over 80 vertebrate species weighing at least $150 \mathrm{~g}$ were recorded, we focus here on only 35 vertebrate taxa that are amenable to transect surveys (Table 2). Details on survey guidelines and field procedures have been described elsewhere (Peres 1999b; Peres \& Lake, 2003). DISTANCE 3.5 software (Thomas et al., 1998) was used to derive population density estimates, using the perpendicular distance data, for those species with sufficient sample sizes. These data were compared to a moderately to heavily hunted unburnt area on the lower Maró river, and this in turn was compared to a moderately to heavily hunted but burnt area on the lower Maró river. These two sites were documented based on extensive personal observations over a 3-year period and by local interviews (see below).

To obtain further information on the effects of the fires, 85 semi-structured household-level interviews were conducted in eight villages affected by the fires (range of village size $=161-630$ residents): São Pedro, Monte Sião, Pascoal, Cachoeira do Aruã, Mentai, Alto Mentai, São José, and Cachoeira do Maró (Fig. 1). A minimum of 10 interviews were conducted in each village, targeting the most experienced hunters and other villagers who were most familiar with these forests both before and after the wildfire.

In aggregate, the information presented here is based on 415 man-days of fieldwork, including $>800 \mathrm{~km}$ walked in both burnt and unburnt forest, village interviews, and net-lines along 20 quarter-hectare forest plots.

\section{Results}

\section{The 'Arapiuns burn'}

The Arapiuns wildfires were triggered following an exceptionally severe 4-month drought (cumulative rainfall for September-December $1987=16.4 \mathrm{~mm}$; Fig. 2) despite attempts by villagers to extinguish the blazes. Virtually all firebreaks, which were deployed in haste after the fire had begun, were reported to have been too narrow or insufficiently deep (into the topsoil) to contain the spread of the fire front. A total of 46 conflagrations could be distinguished along a 110-km stretch of forest from the mouth of the Arapiuns river to Igarapé Mentai (Fig. 1). These fire fronts appear to have stemmed from a single ignition source, and spent several weeks slowly moving westwards towards the Maró river. However, there was considerable spatial variation in the intensity of the burn, and several small unburnt forest patches of usually no more than 1 ha remained isolated within the burnt forest matrix. These unburnt patches (vageados) were typically overshadowed by large tree crowns, 


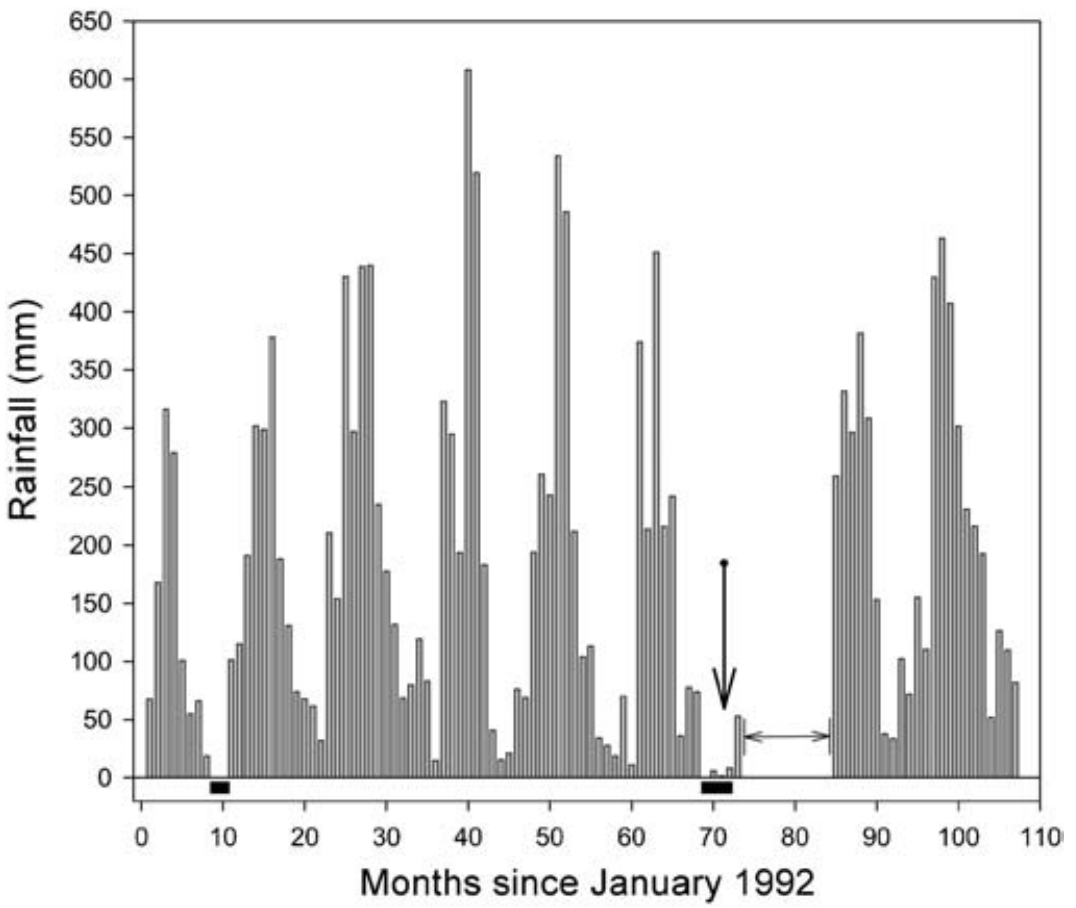

Fig. 2 Monthly rainfall at the nearest meteorological station (Santarém) to the study area over a 9-year period (January 1992-December 2000). Solid rectangles and vertical arrow indicate the timing of severe El Niño-mediated dry seasons and the 'Arapiuns wildfire' in December 1997, respectively. Data are unavailable for the 11-month period indicated by the horizontal arrow. overlapped patches of mostly clay soils, and were reported to be less flammable because of their poor fuel connectivity due to a sparse (and moister) leaf litter and low coarse fuel loads (e.g. dead branches).

The initial impacts of the so-called 'Arapiuns burn' were witnessed by one of us (CAP) over 3 weeks in January 1998, within two weeks after fire that had swept through much of the study area had been extinguished by the first heavy rains in months. This surface fire, which reached heights of up to $3 \mathrm{~m}$ (modal flame height $=20-30 \mathrm{~cm}$ ), had burned an area of $c .1,100 \mathrm{~km}^{2}$ of primary and secondary forest over 15 days in late December 1997, leaving a scorched understorey. The true extent of these wildfires remains unknown because sub-canopy fire scars could not be unambiguously detected on Landsat images. It is unlikely, however, that the total burnt area was overestimated by long-term residents, aided by a 1:50,000 map, and subsequent inspections along the fire-line suggested that the extent of burnt forest farther than $3.5 \mathrm{~km}$ from villages was under-reported.

\section{Short-term responses}

There were marked short-term effects of the fires on forest wildlife. Several signs of direct casualties were witnessed by CAP or reported by local villagers, including skulls and other skeletal remains of tassel-eared marmoset, Hoffmann's titi monkey, red-handed howler monkey, collared peccary Tayassu tajacu, brocket deer Mazama sp., three-toed sloth Bradypus variegatus, two-toed sloth Choloepus didactylus, nine-banded armadillo Dasypus novemcinctus, agouti Dasyprocta aguti, paca Agouti paca, porcupine Coendou sp., spiny rat Proechimys sp., and common possum Didelphis sp.. Additional remains of birds and reptiles that were obviously killed by the fires included skeletal evidence or beaks of large toucans Ramphastos cuvieri, lettered aracaris Pteroglossus inscriptus, small tinamous Crypturellus sp., white-bellied parrots Pionites leucogaster, tortoises (Geochelone denticulata and G. carbonaria) and several species of snake. Although the total number of animals killed directly by the fires could not be estimated, it appeared to be significant for many vertebrate species; one family at Cachoeira do Maró alone reported finding 15 dead agoutis, and many sloths, titi monkeys, toucans, and tortoises on a single day soon after the fire.

Plant mortality in areas affected by surface fires was size dependent both in the immediate aftermath (Peres, 1999a) and up to 15 months later, with seedlings, saplings and small understorey trees succumbing more than larger mid-storey and canopy trees. A vast but unknown proportion of the soil seed bank was also destroyed. The fires affected much of the foraging substrates and prey items for understorey insectivores. Villagers at São Pedro and Cachoeira do Maró reported a sudden extirpation of army ant swarms in burnt forest, as well as dramatic numeric declines in understorey wasp colonies and leaf-litter arthropods such as spiders, centipeds, orthopterans, and cockroaches. 
There was a conspicuous absence of much of the understorey avifauna within two distinctively quiet burnt sites in the vicinities of São Pedro and Cachoeira do Maró, even during peak vocal activity periods, compared to unburnt forest at Novo Lugar, some $40 \mathrm{~km}$ upriver of São Pedro. Mid-storey and canopy dwelling birds appeared to be directly affected by the fires and may have succumbed to smoke asphyxiation. This allegedly took place over a period of several days at any given site, as fires were reduced in intensity once the fine fuel layer was consumed, but continued to smoulder the woody fuels thereafter (C. Aldo, pers. comm.). Species directly affected by fires were often characterised by low mobility (e.g. tortoises), poor climbing ability (e.g. leaf-litter herpetofauna), poor flight capacity (e.g. tinamids), small home ranges (e.g. titi monkeys), or relied heavily on woody shelters such as cavity nests within hollow tree trunks (e.g. toucans and parrots).

Fires reduced food supplies for both arboreal and terrestrial vertebrate frugivores because many maturing fruit crops from small and large trees were either destroyed or aborted. Most understorey shrubs and treelets producing bird-dispersed seeds (e.g. Melastomataceae and Rubiaceae) were directly scorched by the flames, and many overstorey fruit crops were aborted even if tree crowns remained intact, presumably as a response to sub-lethal heat stress. There was unanimous consensus at several villages that ground fires left few unburnt natural refuges in the forest understorey, rendering forest wildlife more vulnerable to subsistence hunters who had become increasingly desperate for alternative sources of food to compensate for the fire damage to food crops.

\section{Medium-term responses}

The apparent decline in bird numbers immediately after the wildfire within burnt forest was confirmed by the understorey mist net-lines operated 10-15 months after the fire. Less than $0.5 \%$ of captures were of birds that had been previously captured in a neighbouring netline, and thus net-lines were considered to be spatially independent. In burnt forest, net-line samples consistently yielded an average capture success $(104.7 \pm$ SE 19.3 captures per 1,000 net hours, $n=603$ captures in 8 net-lines away from the fire-line) that was considerably lower than that in adjacent unburnt forest $(189.4 \pm \mathrm{SE}$ 38.7 captures per 1,000 net hours, $n=1,091$ captures in 8 net-lines). However, the overall avian species richness in the understorey was not affected by the fire: a total of 90 and 87 species were caught within unburnt and burnt forest, respectively (considering only netlines placed away from the fireline). This can be shown in randomised species accumulation curves using EstimateS (Colwell, 2000), in which the effects of capture order was smoothed by averaging captures across all species over 100 simulations (Fig. 3).

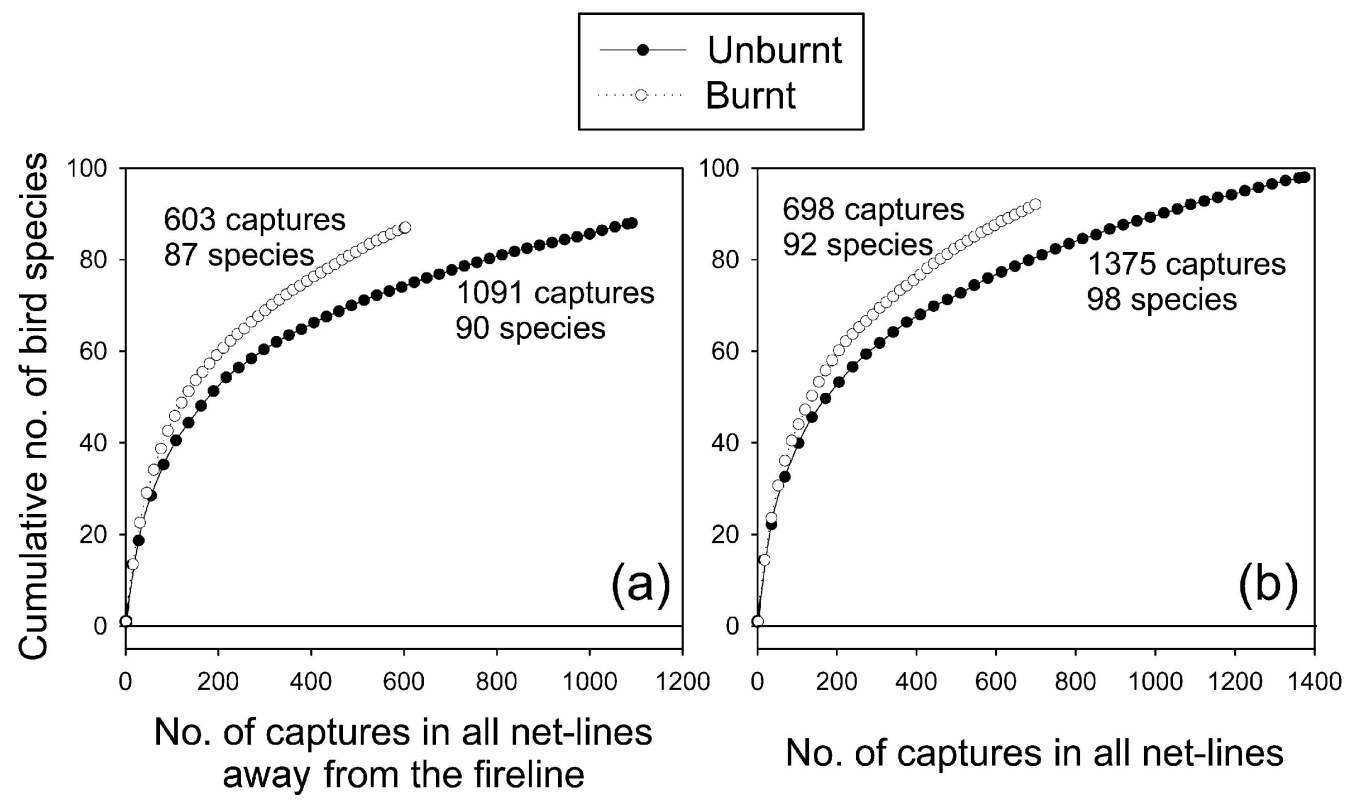

Fig. 3 Bird species accumulation curves over the same amount of sampling effort allocated to understorey net-lines in burnt and unburnt forest. Solid (unburnt forest) and open circles (burnt forest) represent mean values over 100 random simulations, using data from (a) 16 net-lines on both sides of (but at least $500 \mathrm{~m}$ from) the fire-line separating burnt and unburnt forest, and (b) from all 20 net-lines both perpendicular to, and away from, the fire-line (see text for further details). 
Nevertheless, species richness was scale-dependent. Individual net-line samples in burnt forest were significantly less species-rich than those in unburnt forest (mean unburnt $=40.9 \pm$ SE 2.26; mean burnt $=31.25 \pm$ SE 5.97; $t=4.24$, d.f. $=14, \mathrm{P}=0.001$ ), with fewer shaded understorey and more young secondary-growth species being caught in burnt forest (Barlow et al., 2002a).

Surface fires also had consequences for patterns of food resource production for consumers in the various dietary guilds that managed to survive or immigrated into burnt forests. In addition to the mortality of $36 \%$ of mid-storey and canopy trees larger than $10 \mathrm{~cm}$ in diameter at breast height ( $n=2,105$ from the 8 burnt forest plots), and a large (but unknown) proportion of high-climbing lianas, these included a substantially reduced per capita output of fruits and seeds from most large fruiting plants that did survive the fires. However, the sudden reduction in canopy cover produced a dramatically different understorey light environment, with new opportunities for many previously overshadowed species of small trees, shrubs, vines and coarse herbs, many of which responded by accelerating growth, flowering, and fruiting. These included slender bamboo (Guadua sp.), aneleiro Palicourea guianensis, tiririca (Carex spp.), navalhão (Cyperaceae), cipó de fogo (Davilla sp.), batatarana Ipomoea fastigata, maracujá de rato (Passiflora sp.), embaúba (Cecropia sp.), bananinha (Heliconia sp.), and several terrestrial bromeliads (carauatá). The sudden hyper-abundance of light-demanding pioneer species in the understorey, which characterised the post-burn regeneration phase, greatly augmented the biomass of young leaves harvested by terrestrial browsers, some of which responded positively to burnt forests.

Because fire-mediated tree mortality was not random across the pool of plant species in the Arapiuns flora, burnt forests became either more favourable or more hostile environments for particular vertebrate species than expected on the basis of average levels of plant mortality. Interviews conducted in 25 households in four villages consistently reported that tree and liana species producing key resources for vertebrate frugivores succumbed to substantially higher than average mortality rates (Table 3). Species producing fleshy fruits were reportedly more likely to succumb to basal heat stress than those producing wind-dispersed or sclerocarpic fruits such as follicles, samaras and dry pods. Many tree species bearing fleshy fruits are associated with morphological traits that make them more susceptible to lethal heat stress, including thin barks and buttress roots (associated with a deeper leaf litter), both of which were significant morphological correlates of fire-induced mortality (Barlow et al., in press). Moreover, several species that were not necessarily killed by the wildfire aborted a large proportion, if not all, of their maturing fruit crops within days or weeks thereafter, thus exacerbating overall fruit scarcity in the post-burn wet season.

Medium-term responses to surface fires can be illustrated by comparing levels of wildlife abundance 3 years after the fire between sites that had been (i) both burnt and hunted, (ii) hunted but remained unburnt, and (iii) not hunted and unburnt (the 'control'). Persistently hunted burnt forest retained only 22 of 35 medium to large-bodied vertebrate species surveyed in the control site, and seven of those exhibited noticeable population declines (Table 2). Species that were entirely missing from burnt forest included tapir Tapirus terrestris, white-lipped peccary Tayassu peccari, white-fronted capuchin Cebus albifrons, white-nosed bearded saki, giant armadillo Priodontes maximus, razor-billed curassow Mitu tuberosa, piping guan Aburria pipile, and two species of tortoises. Several of these local extinctions were obviously aggravated by the history of hunting pressure in burnt forest. However, some species are unlikely to have survived the wildfire and subsequent habitat changes even in the complete absence of hunting because they are intolerant of secondary forests, which share many of the physiognomic characteristics of burnt forest. For example, the pitheciine primates (bearded and baldfaced sakis) could be found in unburnt and moderately hunted forests, but were either extirpated or had severely declined in burnt forest, suggesting that they were more sensitive to fire-disturbance than hunting pressure. Several other species also had their hunting-mediated declines aggravated in burnt forest, but shifts in abundance were reversed for those species that were either favoured in some way by fire-disturbance or enjoyed some protection from hunters under the newly regenerated thick cover. Distinguishing the effects of game harvest and fire-induced changes is difficult because all burnt areas in the Arapiuns-Maró basin have a recent history of hunting.

\section{Socioeconomic costs of surface fires}

Interviews and questionnaires at all surveyed households clearly indicated that wildfires damaged food crops and domesticated fruit trees, and substantially degraded the social benefits obtained from primary forests through direct impact on key resource populations. Almost all households reported losses in direct and indirect income from subsistence crops. For example, $96 \%$ of the 120 cassava plots or roçados (mean area $=$ $1.35 \mathrm{ha}$ ) cultivated within the São Pedro village territory $\left(273 \mathrm{~km}^{2}\right)$ were partly or entirely destroyed by the fire. Key perennial crops and fruit trees were also badly damaged. One household alone reported that 500 Euterpe (açaí) palms and 300 Theobroma longifolia (cupuaçú) trees 
Table 3 Principal food species used by forest vertebrate frugivores in the Arapiuns-Maró river basins known to be particularly sensitive to surface fires.

\begin{tabular}{|c|c|c|c|c|}
\hline Local name & Species (Family) & Main effect ${ }^{1}$ & Part eaten ${ }^{5}$ & Period available \\
\hline Tapurú & Brosimum sp. (Moraceae) & $\mathrm{I}$ & YS, Fr & Sep-Nov \\
\hline Amapá & Brosimum rubescens (Moraceae) & $\mathrm{I}$ & YS, Fr & Year round \\
\hline Caxinguba & Ficus cf. maxima & I & $\mathrm{Fr}$ & Year round \\
\hline Apuí & Ficus sp. (Moraceae) & $\mathrm{I}, \mathrm{II}$ & Fr & Year round \\
\hline Tatajuba & Bagassa guianensis (Moraceae) & I & Fr & Jan-Mar \\
\hline Mão de raposa & Unidentified Moraceae & I & Fr & $?$ \\
\hline Marupá & Simarouba amara (Simaroubaceae) & $\mathrm{I}, \mathrm{II}$ & Fr & $?$ \\
\hline Taperebá & Spondias mombin (Anacardiaceae) & I & Fr & Mar-Apr, Sep-Nov \\
\hline Tapiririca & Tapirira guianensis (Anacardiaceae) & $\mathrm{I}$ & Fr & Feb-Apr \\
\hline Murucí & Byrsonima sp. (Malpighiaceae) & I & Fr & Year round \\
\hline Marfim & Unidentified & $\mathrm{I}, \mathrm{II}$ & Fr & Sep-Oct \\
\hline Bucha, Buxeira & Unidentified Apocynaceae & I & Fr & Jul-Sep \\
\hline Sorva & Couma macrocarpa (Apocynaceae) & $\mathrm{I}$ & $\mathrm{Fr}$ & Jan-Feb \\
\hline Sucuba & Himatanthus sucuuba (Apocynaceae) & $\mathrm{I}$ & Fr, YS & $?$ \\
\hline Muúba $^{2}$ & Bellucia spp. (Melostomataceae) & $\mathrm{I}$ & Fr & Year round \\
\hline Piquiá $^{2}$ & Caryocar sp. (Caryocaraceae) & II & Fr & Feb-Mar \\
\hline Envira surucucu & Duguetia sp. (Annonaceae) & I & $\mathrm{Fr}$ & Jan-Mar \\
\hline Breu & Protium sp. (Burseraceae) & $\mathrm{I}$ & Fr & Jan-Apr \\
\hline Fava sururu & Parkia pendula (Leg. Mimosoidae) & $\mathrm{I}$ & $\mathrm{Fw}, \mathrm{YS}$ & Jul-Sep \\
\hline Cumarú & Dypteryx odorata (Leg.) & II & Fr & May-Jun \\
\hline Jutaî $^{2}$ & Hymenaea courbaril & II & Fr & May-Jul \\
\hline Paracaxí & Unidentified & I & Fr & $?$ \\
\hline Itaúba & Mezilaurus itauba (Lauraceae) & I & Fr & $?$ \\
\hline Abil & Pouteria sp. (Sapotaceae) & II & Fr & Jan-Jul \\
\hline Maparajuba & Manilkara paraensis (Sapotaceae) & $\mathrm{I}, \mathrm{II}$ & Fr & Dec-Feb \\
\hline Bacuri grande & Rheedia/Platonia sp. (Guttiferae) & I, II & Fr & $?$ \\
\hline Uxí & Unidentified Humiriaceae & II & Fr & Mar-Jun \\
\hline Uxí liso & Endopleura uchi (Humiriaceae) & I & $\mathrm{Fr}$ & Mar \\
\hline Uxirana & Unidentified Humiriaceae & II & Fr & Feb-Jun \\
\hline Umerí & Unidentified Humiriaceae & I & Fr & $?$ \\
\hline Castanha de macaco & Unidentified Chrysobalanaceae & $\mathrm{I}$ & Fr & Jan-Feb \\
\hline Virola/Ucuuba & Virola sp. (Myristicaceae) & I & $\mathrm{Fr}$ & Jan-Mar \\
\hline Bacaba $^{2,3}$ & Oenocarpus bacaba (Arecaceae) & $\mathrm{I}, \mathrm{II}$ & Fr & Sep-Mar \\
\hline Açaí & Euterpe precatoria (Arecaceae) & $\mathrm{I}, \mathrm{II}$ & Fr & Year round \\
\hline Curuá/Palha ${ }^{4}$ & Attalea sp. (Arecaceae) & $\mathrm{I}, \mathrm{II}$ & Fr & Year round \\
\hline Tucumã & Astrocaryum tucuma (Arecaceae) & I & Fr & Oct-Mar \\
\hline Jará do Igapó & Leopoldinia sp. (Arecaceae) & I & Fr & Mar-Apr \\
\hline Buriti & Mauritia flexuosa (Arecaceae) & $\mathrm{I}$ & Fr & Year round \\
\hline
\end{tabular}

${ }^{1}$ Main fire-induced effects: I, succumbed to high mortality rates; II, typically aborted a significant proportion of maturing fruit and/or seed crops following sub-lethal flame contact, but were not necessarily killed.

${ }^{2} \mathrm{~A}$ few reports indicated that these species were fairly fire-tolerant.

${ }^{3} \mathrm{~A}$ few reports indicated that this species was fire-intolerant due to its superficial root system.

${ }^{4}$ Very sensitive to thermal stress but capable of resprouting thereafter.

${ }^{5}$ YS, young seed; Fr, fruit pulp, Fw, flower.

had been killed by the fire. This is equivalent to an annual loss in household revenues of $\mathrm{R} \$ 4,000-5,000$ (US $\$ 3,571-4,463$ in January 1998) based on conservative estimates of the substitution value of these goods at the nearest market town (Santarém). These figures exceed the annual Brazilian minimum salary (the typical wage of the vast majority of the urban workforce in Amazonia) by a factor of 3.0-3.8.

The destruction of small infrastructural investments and important sources of non-timber forest products rendered burnt forest largely worthless for any extractive effort. Important forest resources affected included the destruction of fibre material from vines and aroid hemiepiphytes used in housing construction and basketry work (e.g. Heteropsis aff. spruceana and Philodendron sp.), understorey and arborescent palms that are extensively used in roof thatching (e.g. curuá Attalea cf. microcarpa), important latex trees (Hevea brasiliensis and Brosimum spp.), wild fruit trees (e.g. several arborescent palms such as Euterpe precatoria), medicinal plants, and several 
species of game vertebrates. For instance, subsistence hunters at Cachoeira do Maró and São Pedro reported that post-burn hunting forays on foot from the nearest village required an additional $2-4 \mathrm{~h}$ walking radius in order to obtain game yields comparable to those prior to the fire. Forest mammals have traditionally comprised the most important sources of animal protein along the Maró and Arapiuns because local fisheries are extremely unproductive in these nutrient-poor rivers. Local sales of chilled bovine meat from Santarém have recently increased for the first time, suggesting that bushmeat has become scarce.

Large patches of burnt forest were widely reported to have become inaccessible for extractive enterprises because an impenetrable understorey was formed by the pulse of light-demanding pioneer seedlings that were recruited following the wildfire. This suggests that fireinduced mortality in the soil seed bank was lower for small-seeded plants that tend to recruit within canopy gaps than for large-seeded shade-tolerant species. This triggered a negative feed-back process that offered at least temporary protection to several species of game vertebrates that sought cover within thick undergrowth, such as in areas dominated by slender bamboo (Guadua sp.). Game species that benefited in this way included forest tortoises, nine-banded armadillo, agouti, paca, collared peccaries, brocket deer, and common guan Penelope spp. As a consequence, there was a shift in hunting techniques used in burnt forest from forays on foot and sit-and-wait ambushes from elevated platforms (esperas) to shotgun traps. Many reports indicated that the abundance of the most important terrestrial vertebrates in burnt forest increased within these inaccessible refugia, and may now exceed densities in previously unburnt but overhunted forests. However, it remains unclear for how long hunters will be discouraged from pursuing vertebrate prey in dense understorey as the post-burn regeneration phase progresses, and recent local reports suggest that areas that suffered only light burns are already becoming suitable for hunting.

Surface fires also aggravated the pressure for frontier expansion, as the decreased quality of life in areas surrounded by burnt forest encouraged people to move upstream into previously uninhabited areas. In addition, the overall shortage of (or lack of access to) extractive commodities in burnt forest is expected to further catalyse the transition from a subsistence to a money economy, further exacerbating the pressure to intensify production of cash crops at the expense of wildlife habitat. On the other hand, pressure on local resources has been recently relieved by higher rates of rural exodus into urban centers, which has been driven primarily by young villagers, most likely because of the greater adversity induced by the burn.

\section{Discussion}

\section{Faunal 'secondarization' in burnt forests}

Although there was considerable spatial variation in the rate of tree mortality (range $=27.1-40.3 \%, N=8$ ) and degree of canopy openness (range $=11.7-31.8 \%, N=8$ ) across burnt forest plots, the habitat structure of all firedisturbed areas, compared to unburnt control plots, was visibly disfigured up to 1 year after the wildfire. Fireinduced changes in forest structure included dramatic increases in canopy fracture, higher rates of tree fall, a downward shift in the vertical stratification of foliage density, and a marked increase in the amount of light reaching the understorey and forest floor. The massive scale of these changes have little in common with the natural disturbance regime of Amazonian forests over long time scales, but are comparable to those found in intensively logged-over and bulldozer-disturbed forests where the remaining basal area of live trees is $<40 \%$ of that in unlogged primary forest. Primary forests that have been affected by a single wildfire are analogous to a large-scale 'pseudo-gap' condition, with virtually the entire residual stand occupying the interstices of a diffuse canopy gap in which virtually the entire seed-bank, and all seedlings and saplings, have been killed.

This is expected to have detrimental effects on (i) primary forest specialists that are largely restricted to the moist, shaded understorey; (ii) arboreal frugivores relying on high canopy continuity or high density of fruit patches; and (iii) a number of resource specialists relying heavily on plant species or microhabitats that were either badly damaged by the fire or intolerant of the new pseudo-gap conditions. Examples of shifts in faunal abundance mediated by the new trophic structure of fire-disturbed forest include the local extinction or marked decline of (i) army-ant swarms and several species of army-ant followers, including large antbirds (Barlow et al., 2002a) and trumpeters; (ii) ripe-fruit specialists (e.g. piping guan, capuchins Cebus apella and C. albifrons, and spider monkeys) relying heavily on trees and woody lianas bearing fleshy fruits, many of which were badly ravaged by the fire; and (iii) specialized seed predators, including the pitheciine primates and several species of large psittacids including true parrots (Amazona spp.) and macaws (Ara spp.).

On the other hand, fire-disturbance produced a pulse of young foliage in the understorey which apparently favoured large terrestrial browsers and arboreal folivores feeding selectively on new leaves. These included paca, both species of brocket deer Mazama gouazoubira and M. americana, and to some degree howler monkeys. A few terrestrial frugivore/insectivores that tend to do well in Amazonian secondary forests, including nine-banded 
armadillo, collared peccary, the smaller of the two species of common guan (Penelope superciliaris), woodquail Odontophorus gujanensis, and several species of small tinamous (Crypturellus spp.), also received a boost in burnt forest, particularly with the added protection from the dense undergrowth.

Patterns of species turn-over and shifts in relative abundance from unburnt to burnt forest are similar to those from primary forest to young secondary growth recovering from swidden agriculture. We could therefore label these changes as the community-wide 'secondarization' of once-burnt Amazonian forests. However secondary forests often have high rates of seed delivery by animal dispersal agents from adjacent primary forests, and many years of recovery in the absence of additional fire disturbance. These processes may proceed in the long-term, but there is no doubt that tropical forest fire-disturbance will benefit those species that consistently do well in secondary-growth mosaics to the detriment of increasingly threatened primary forest specialists.

\section{Future prospects of fire-prone Amazonian forest}

The ecological consequences of surface wildfires in tropical rainforests are devastating and perhaps more severe in central Amazonia than those reported for more peripheral and drier parts of the region (Cochrane \& Schulze, 1999, O. Carvalho, pers. comm) or elsewhere in the tropics (e.g. Kinnaird \& O'Brien, 1998). It has been estimated that approximately $400,000 \mathrm{~km}^{2}$ of the remaining forest cover in Brazilian Amazonia is vulnerable to surface fires (Nepstad et al., 1999b). Much of these flammable forests are used, managed, or otherwise controlled by rural communities, including Indians, caboclos and more recent immigrants from southern Brazil. Extractive and agricultural enterprises in seasonally dry forests will unavoidably be forced to coexist with the increasingly greater risk of recurrent fires. This will require cultural adaptation, as fire prevention practices have never been a part of the cultural ecology of rural Amazonians, which developed largely in the absence of catastrophic wildfires. This will demand additional labour input, and further strain local economies, generating discontent and resentment in relation to insufficient inputs from government agencies.

We expect fire-return intervals in fire-prone Amazonian forests to become about two orders of magnitude shorter ( $<10$ years) than those suggested by carbon-dating studies of charcoal from prehistoric wildfires (500-1200 years; Sanford et al., 1985; Turcq et al., 1998). It is surprising, therefore, that fire prevention issues have not gained greater prominence in regional forest management policy in the most threatened parts of Amazonia, and
5 years after the 'Arapiuns burn' the issue seems to be largely forgotten in many areas that were affected. For instance, the management plan of the Tapajós-Arapiuns Extractive Reserve, which was drafted after the 1997 fire (IBAMA, 1999), makes no mention of fire management and suppression practices, although the IBAMA office in Santarém has carried out a short training workshop to increase local awareness of the threats posed by a subsequent wildfire.

A complicating factor is the increasing temptation for local communities to cash in on the timber capital of their forest through legal or illegal logging. Such short-term revenue alternatives are favoured by political leaders of many local communities across Brazilian Amazonia, who find support in the often misleading notion that small-scale logging practices in communitymanaged forests are benign and sustainable. In the context of seasonally dry forests, this issue is critical because even offtakes of a few canopy trees through selective logging practices could dramatically elevate the local flammability risk of previously unburnt forest (Nepstad et al., 1999; Cochrane, 2000). At present, local communities along the Arapiuns and Maró target a small set of at most eight timber species (itaúba Mezilaurus itauba, Lauraceae; pau d'arco Tabebuia serratifolia, Bignoniaceae; cupiúba Goupia glabra, Caelastracea; acariquara Minquartia guianensis, Olacaceae; maçaranduba Manilkara sp., Sapotaceae; and preciosa Aniba canelilla, Lauraceae). These are felled at different rates and primarily for local use, but the roundlogs tend to be sawn on site, rather than dragged, thus minimising the collateral damage to the overall stand. This is in sharp contrast to the large-scale commercial logging operation that extracted $62,000 \mathrm{~m}^{3}$ of timber from the 25 most valuable species in 1992-1996 in a controversial but legal leasehold along the lower Arapiuns river (C. Aldo, pers. comm.). The entire area leased by this company was subsequently engulfed during the Arapiuns burn, and the flame front often reached the crowns of mid-storey trees. Nevertheless new plans to commercially $\log$ a much larger area of primary forest in the upper Maró river are already in place.

The population declines of mid-sized to large game vertebrates in burnt forests forced many villagers to travel farther to hunt. This expanded the radius of game depletion into unburnt areas that had previously been underexploited. But the long-term prospects for forest wildlife conservation in once-burnt Amazonian forests will depend on the return interval of potentially recurrent fires, which are likely to have far greater detrimental effects on the vertebrate fauna than the first fire. Wildlife and plant populations at the Tapajós-Madeira interfluvium have been gradually recovering from the 1997 fire, and are expected to continue doing so in the absence 
of additional fire disturbance. A recurrent fire, however, would consume a large proportion of the fuel load accumulated from the initial fire-induced plant mortality, probably releasing enough energy to reach above the mid-storey, and could kill an additional $40-50 \%$ of all living trees remaining after the first burn (Cochrane \& Schulze, 1999). Large trees would no longer have any appreciable survival advantage as they did during the initial fire (Peres, 1999a; Haugaasen, 2000). The high mortality rate of the remaining large trees would result in a collapse of above ground live biomass, further thinning an already sparse canopy cover. The second fire would probably be the turning point in an irreversible transition from evergreen, closed-canopy forest to a scrub savannah punctuated by a few fire-tolerant large trees. Preliminary support for this prognosis comes from a site along the lower Arapiuns river (Lago Grande) where forests subjected to fires twice within 10 years (1988-98) or three times since 1984 now have the characteristics of anthropogenic campos limpos (Amazonian edaphic savannah enclaves with little or no tree cover) while still bearing dead snags of emergent trees in a once continuous canopy layer. We expect that such twiceor thrice-burnt 'forest' will harbour only a fraction of its original vertebrate fauna, whilst creating opportunities for invasions by second-growth and cerrado species that have been expanding their distributions over the last three decades. Recurrent fires must therefore be avoided at all costs because the severity of a second burn will be significantly greater (Cochrane et al., 1999; Cochrane \& Schulze 1999; Nepstad et al., 1999). Greater government involvement will be needed to share this burden with local communities. However, because El Niño events are becoming both more frequent and more severe (Trenberth et al., 1996; Dunbar, 2000) it seems unlikely that the canopy of once-burnt forests will sufficiently close in time to prevent future severe droughts from breaking the forest flammability threshold.

Recurrent fires with return times of years or decades rather than millennia must be suppressed at all costs in Amazonia. Although frequent wildfires are an intricate part of the long-term dynamics of fire-climax systems, they are unprecedented in the ecological history of evergreen tropical forests, and the predicament of wildlife populations in seasonally dry Amazonian forests has never seemed so uncertain. Wildfires are likely to be repeated on a much larger spatial scale and with shorter return times, and to considerably expand their frontiers into previously unburnt forests. The dynamics of fire-disturbance will thus become a decisive ingredient in the future conservation prospects of flammable forest ecosystems, requiring enormous political will from national and local governments to avert, minimize or remedy the threats posed by wildfires.

\section{Acknowledgements}

This study was funded by the Center for Applied Biodiversity Science of Conservation International. Jos Barlow's fieldwork was funded by a NERC PhD studentship at the University of East Anglia. We are especially grateful to the political leadership of the Reserva Extrativista do Tapajós-Arapiuns and to all villagers along the Rio Maró and Arapiuns who generously shared information with us. Rionaldo and Edith dos Santos, and Nan, provided crucial logistical assistance during all stages of the project, and Anthony Rylands provided useful comments on the manuscript.

\section{References}

Baillie, J. \& Groombridge, B. 1996. IUCN Red List of Threatened Animals. International Union for Conservation of Nature, Gland, Switzerland.

Barlow, J., Haugaasen, T. \& Peres, C.A. (2002a) Effects of ground wildfires on understorey bird assemblages in Amazonian forests. Biological Conservation, 105, 157-169.

Barlow, J., Haugaasen, T. \& Peres, C.A. (2002b) Sympatry of Black-faced Leucopternis melanops and White-browed hawks L. kuhli along the lower Rio Tapajós, Pará, Brazil. Cotinga, 18, 77-79.

Barlow, J., Lagan, B.O. \& Peres, C.A. (in press) Morphological correlates of fire-induced tree mortality in a central Amazonian forest. Journal of Tropical Ecology.

Buckland, S.T., Anderson, D.R., Burnham, K.P. \& Laake, J.L. (1993) Distance Sampling: Estimating Abundance of Biological Populations. Chapman \& Hall, London, UK.

Cochrane, M.A. (2000) Compreendendo o significado das queimadas na floresta Amazônica. Ciência Hoje, 13, 26-31.

Cochrane, M.A. \& Schulze, M.D. (1999) Fire as a recurrent event in tropical forests of the Eastern Amazon: effects on forest structure, biomass, and species composition. Biotropica, 31, 2-16.

Cochrane, M.A., Alencar, A., Schulze, M.D., Souza, C.M., Nepstad, D.C., Lefebvre, P. \& Davidson, E.A. (1999) Positive feedbacks in the fire dynamics of closed canopy tropical forests. Science, 284, 1832-1835.

Colwell, R.K. (2000) EstimateS: Statistical Estimation of Species Richness and Shared Species from Samples.

http:/ / viceroy.eeb.uconn.edu/estimates [accessed 8 November 2002].

Dunbar, R.B. (2000) El Niño - Clues from corals. Nature, 407, 956-959.

Goldammer, J.G. (1999) Forests on fire. Science, 284, 1782-1783.

GreenPeace (2001) Brazil's Amazon National Park - Protection in Name Alone. http: / / www.greenpeaceusa.org/forests / governmenttext.htm [accessed 12 December 2001].

Haugaasen, T. (2000) Effects of ground fires on understorey birds in central Amazonia, Brazil. MSc thesis, University of East Anglia, Norwich, UK.

Holdsworth, A.R. \& Uhl, C. (1997) Fire in Amazonian selectively logged rain forest and the potential for fire reduction. Ecological Applications, 7, 713-725. 
IBAMA (1999) Plano de Utilização da Reserva Extrativista TapajósArapiuns. Instituto Brasileiro do Meio Ambiente e dos Recursos Naturais Renováveis, Brasília, D.F., Brazil

Kinnaird, M.F. \& O’Brien, T.G. (1998) Ecological effects of wildfire on lowland rainforest in Sumatra. Conservation Biology, 12, 954-956.

Nepstad, D.C., Verissimo, A., Alencar, A., Nobre, C., Lima, E., Lefebre, P., Schlesinger, P., Potter, C., Moutinho, P., Mendoza, E., Cochrane, M. \& Brooks, V. (1999a) Large-scale impoverishment of Amazonian forests by logging and fire. Nature, 398, 505-508.

Nepstad, D.C., Moreira A.G. \& Alencar A.A. (1999b) Flames in the Rain Forest: Origins, Impacts and Alternatives to Amazonian Fire. Pilot Program to Conserve the Brazilian Rainforest. World Bank, Brasília, D.F., Brazil.

Oren, D.C. \& Parker, I.T.A. (1997) Avifauna of the Tapajós National Park and vicinity, Amazonian Brazil. Ornithological Monographs, 48, 493-525.

Peres, C.A. (1999a) Ground fires as agents of mortality in a Central Amazonian forest. Journal of Tropical Ecology, 15, 535-541.

Peres, C.A. (1999b) General guidelines for standardizing linetransect surveys of tropical forest primates. Neotropical Primates, 7, 11-16.

Peres, C.A. (2000) Ecological criteria and indicators for community managed forests. In Developing Criteria and Indicators of Community managed Forests as Assessment and Learning Tools: Objectives, Methodologies and Results (eds N. Burford de Oliveira, C. McDougall, B. Ricthie, H. Hartanto, M. Haggith \& S. Setyawati), pp. 271-281. Center for International Forestry Research, Bogor, Indonesia.

Peres, C.A. \& Lake, I.R. (2003) Extent of nontimber resource extraction in undefended tropical forests: an accessibility analysis in the Amazon basin with special emphasis on game vertebrates. Conservation Biology.

Rylands, A.B., Mittermeier, R.A. \& Rodriguez-Luna, E. (1995) A species list for the New World primates (Platyrrhini): distribution by country, endemism, and conservation status according to the Mace-Lande system. Neotropical Primates, 3, $113-160$.
Sanford, R.L., Saldarriaga, J., Clark, K.E., Uhl, C. \& Herrera, R. (1985) Amazon rain-forest fires. Science, 227, 53-55.

Siegert, F., Ruecker, G., Hinrichs, A. \& Hoffmannk, A.A. (2001) Increased damage from fires in logged forests during droughts caused by El Niño. Nature, 414, 437-440.

Stotz, D.F., Fitzpatrick, J.W., Parker, T.A. \& Moskovits, D.K. (1996) Neotropical birds: Ecology and Conservation. University of Chicago Press, Chicago, USA.

Trenberth, K.E. \& Hoar, T.J. (1996) The 1990-95 El NinõSouthern Oscillation event: longest on record. Geophysical Research Lettters, 23, 57-60.

Turcq, B., Sifeddine, A., Martin, L., Absy, M.L., Soubies, F., Suguio, K. \& Volkmer-Ribeiro, C. (1998) Amazonia rainforest fires: A lacustrine record of 7000 years. Ambio, 27, $139-142$.

Uhl, C. \& Buschbacher, R. (1985) A disturbing synergism between cattle ranch burning practices and selective tree harvesting in the Eastern Amazon. Biotropica, 14, 265-268.

\section{Biographical sketches}

Dr Carlos Peres has had a life-long interest in the ecology and conservation of wildlife populations in Neotropical forests. He has spent the last two decades working on the responses of forest vertebrates to different forms of anthropogenic disturbance including hunting, forest fragmentation and wildfires.

Jos Barlow is interested in the ecological effects of surface fires in tropical ecosystems and in different disturbance regimes in Amazonian forests.

Tor Haugaasen has been carrying out research for his $\mathrm{PhD}$ on the consequences of seasonality and landscape heterogeneity for forest vertebrate assemblages in Amazonian forests. 